\title{
Pemahaman dan kemampuan siswa sekolah menengah pertama dalam menulis surat dinas berdasarkan struktur surat
}

\author{
Yulia Nelfita ${ }^{1^{*}}$, Yenni Hayati ${ }^{1}$ \\ ${ }^{1}$ Universitas Negeri Padang, Indonesia
}

\begin{tabular}{l} 
Article Info \\
\hline Article history: \\
Received Mar $21^{\text {st }}, 2021$ \\
Revised Apr19 $9^{\text {th }}, 2021$ \\
Accepted Apr $30^{\text {th }}, 2021$ \\
\hline
\end{tabular}

\section{Keyword:}

Surat dinas

Kemampuan menulis

Siswa SMP

\begin{abstract}
Teaching materials regarding an official letter of request for permission prepared by students have several mistakes, namely in determining the composition of the official letter. Weak skills in compiling official letters for junior high school (SMP) students are thought to be caused by their low understanding and ability to write official letters. So this study aims to analyze the understanding and ability of junior high school level students in writing official letters. This research method is a quantitative method. The number of samples in this study was 60 students. The research instrument used was the official letter writing test. The results showed that generally, the level of ability to write official letters of students was in the sufficient category. So that there needs to be more special attention from the teacher to improve the understanding and ability of junior high school students in compiling official letters based on the structure of the letter.
\end{abstract}

(C) 2021 The Authors. Published by IICET.

This is an open access article under the CC BY-NC-SA license (https://creativecommons.org/licenses/by-nc-sa/4.0)

\section{Corresponding Author:}

Yulia Nelfita,

Universitas Negeri Padang

Email: yulianelfita16@gmail.com

\section{Pendahuluan}

Bahasa Indonesia yang diajarkan disekolah merupakan bagian yang sangat penting, karena dengan pembelajaran bahasa tingkat kemampuan berpikir seseorang akan dapat terlihat (Jihad, 2012). dalam pembelajara bahasa seseorang akan menelaah dan menilai penggunaan kata dan kalimat yang baik dan benar. hal tersebut akan berimplikasi pada kemampuan berpikir seseorang. Salah satu contohnya yaitu anak bisa belajar membaca dan melatih diri untuk meningkatkan kemamuan membaca dengan pemahaman bahasa Indonesia yang baik. Dengan demikian dapat dinyatakan bahwa bahasa merupakan faktor penunjang keberhasilan mata pelajaran lainnya.

Bahasa Indonesia merupakan alat untuk berkomunikasi secara lisan dan tulisan (Mahsun, 2014). Salah satu komunikasi lisan adalah dengan berbicara, berdiskusi dan lainnya. Berkomunikasi adalah memahami dan mengungkapkan informasi, pikiran, perasaan, dan mengembangkan ilmu pengetahuan, teknologi, dan budaya (Rusman, 2013). Sedangkan komunikasi lisan dapat diamati pada kegiatan menulis, misalnya menulis surat. Salah satu penerapan bahasa Indonesia yang baik adalah dalam penulisan surat.

Menurut (Dalman, 2014) “Surat adalah sarana untuk menyampaikan pikiran, isi hati, maksud, atau kehendak pada orang lain melalui bahasa tulis dengan mempergunakan kertas sebagai medianya". Surat merupakan sarana berkomunikasi dan berinteraksi sesama manusia melalui media tulisan (Tarigan, 2013). Surat sebagai bentuk perwakilan seseorang dalam menyampaikan maksud kepada penerima surat harus 
mampu menuliskan maksud dan tujuan secara efektif sesuai dengan Bahasa Indonesia yang baik dan benar (Zabadi, Fairul, Mu' jizah, Murniah, Dad, Sutejo, Parjopo, dan Mujiati, Nok, 2013).

Bahasa yang digunakan dalam surat tentu memiliki ketentuan dan kriteria tertentu, agar pesan yang disampaikan melalui media tulisan tersebut dapat dipahami secara benar dan tepat sesuai dengan maksud pengirim surat (Zainurrahman, 2011). Surat yang disampaikan kepada penerima misalnya keluarga atau kelompok terpelajar tentu bisa memahami maksud bahasa surat tersebut. Namun, beda halnya jika surat yang menggunakan bahasa asing yang tergolong sulit dipahami kemudian surat tersebut diberikan atau ditujukan pada penerima yang tidak memahami bahasa tersebut, maka dikhawatirkan akan muncul kesalahpahaman dalam memaknai isi surat tersebut (Achmad, 2011). Surat sebagai bentuk penyampaian informasi dan menyalurkan maksud seseorang kepada orang lain haruslah patuh pada kaidah Bahasa Indonesia yang baik dan benar (Nurgiyantoro, 2014).

Salah satu aspek keterampilan berbahasa yang cukup kompleks atau cukup penting adalah pada aspek keterampilan menulis (Pamungkas, 2012). Keterampilan menulis memiliki kedudukan yang sangat tinggi dibandingkan aspek-aspek lain seperti membaca dan mendengarkan. Keterampilan menulis bukanlah yang mudah, karena siswa mampu membaca surat belum tentu dapat menulis surat yang baik dan benar (Suprapto, 2014). Hal ini haruslah mendapat perhatian serius dari berbagai pihak terutama guru sebagai mentor dalam mendidik siswa di sekolah.

Di dunia pendidikan dari jenjang sekolah dasar, menengah dan sampai pada jenjang perguruan tinggi, mata pelajaran bahasa Indonesia merupakan mata pelajaran yang penting (Suparno, 2011). Dalam pelajaran bahasa Indonesia, sama halnya dengan penjabaran sebelumnya, harus mengajarkan empat aspek keterampilan berbahasa. Salah satu keterampilan berbahasa yang perlu diajarkan dan dilatih dalam dunia pendidikan adalah keterampilan menulis, di samping berbicara, membaca dan menyimak. Oleh sebab itu, menulis merupakan keterampilan yang harus dimiliki semua siswa agar dapat memahami bahasa yang digunakan orang lain secara tertulis (Dalman, Keterampilan Menulis, 2018).

Sebagai salah satu contoh kegiatan keahlian menulis yang diajarkan di sekolah yaitu kegiatan menyusun surat dinas. Menulis surat dinas sudah diajarkan pada jenjang pendidikan SMP Kelas VIII. Seringkali siswa dituntut untuk mampu menulis sebuah surat khususnya surat dinas (Rahman, 2017).

Observasi yang penulis amati pada bulan Januari 2021, fenomena yang terjadi di SMP 03 Tapung dalam menulis surat dinas yakni keinginan atau minat siswa dalam menulis surat dinas tergolong cukup yang dibuktikan dari hasil latihan yang diberikan guru kepada siswa tersebut. Dari hasil pengamatan awal peneliti, guru bahasa Indonesia yang mengampu di SMP 03 Tapung menemukan menulis merupakan sebuah persoalan yang kompleks. umumnya siswa tidak berminat dalam aktivitas menulis, khususnya untuk menyusun surat dinas. Dari bahan ajar mengenai surat dinas permintaan izin yang disusun siswa, terdapat sejumlah kekeliruan yang lumayan banyak yakni dalam menetapkan susunan surat dinas. Perihal yang menyebabkan siswa tidak tertarik untuk menulis surat yakni pertumbuhan jaman. Lemahnya kecakapan siswa untuk menyusun surat dinas menyebabkan guru bahasa Indonesia menjadi semakin mengamati hal itu serta semakin membina siswanya supaya ahli untuk menyusun khususnya untuk menyusun surat dinas ditinjau dari sisi kecakapan siswa menulis surat sesuai susunan surat dinas. Kemudian setelah semuanya terealisasi lalu hasil belajar siswa yang diinginkan yaitu siswa ahli untuk menyusun surat dinas.

Penelitian mengenai pemahaman siswa dalam menulis surat dinas sangat penting dilakukan agar dapat mengukur kendala siswa dalam menulis surat dan menemukan solusinya. Penelitian mengenai kemampuan menulis surat juga pernah diteliti oleh beberapa peneliti lainnya. Diantaranya adalah oleh (Kemal, 2013) yang berjudul Keterampilan Menulis Surat Dinas. Dalam penelitian (Kemal, 2013) menemukan nilai rata-rata tingkat kemampuan keterampilan menulis surat dinas pada siswa adalah 82 hal ini menunjukan bahwa kemampuan keterampilan menulis surat dinas pada siswa Kelas VIII SMP Negeri 16 Banda Aceh Tahun Pelajaran 2011-2012 berada pada kategori baik.

Penelitian lainnya oleh (Febri Andira, Adnan, M. Yamin, 2017) yang berjudul Kemampuan menulis surat resmi siswa kelas V SDN Garot Aceh Besar. Dalam penelitian (Febri Andira, Adnan, M. Yamin, 2017) menemukan nilai rata- rata siswa berada pada kategori sangat mampu. Dengan demikian, siswa kelas V SD Negeri Garot Aceh Besar telah memiliki kemampuan yang sangat mampu dalam menulis surat resmi.

Penelitian relevan selanjutnya oleh (Kurniawan, 2017) yang berjudul Kemampuan Mahasasiswa PGSD FKIP Universitas Riau dalam Menulis Surat Resmi. Penelitian (Kurniawan, 2017) menemukan keterampilan menulis surat resmi mahasiswa PGSD FKIP Universitas Riau adalah baik. Penelitian selanjutnya oleh (Idayanti, 2019) yang berjudul Kemampuan Menulis Surat Resmi Mahasiswa PGSD FKIP Universitas Riau. Penelitian (Idayanti, 2019) keterampilan menulis surat resmi mahasiswa PGSD FKIP Universitas Riau adalah 
baik. Penelitian relevan lainnya adalah oleh (Darmawati, 2019) yang berjudul Kemampuan Menulis Surat Resmi dengan Pendekatan Kontekstual Siswa Kelas VII SMPN 8 Palopo. Penelitian (Darmawati, 2019) menemukan Dari ketuntasan belajar siswa yang disesuaikan dengan KKM terakhir (posttest) sudah mampu dinyatakan apabila jumlah siswa mencapai $78 \%$ yang memeroleh nilai $\geq 76$.

Penelitian lainnya oleh (Agustin, 2019) yang berjudul Kemampuan Menulis Surat Dinas Siswa kelas VII SMP N 11 Kediri. Penelitian (Agustin, 2019) menemukan secara klasikal kemampuan siswa kelas VII SMP Negeri 11 Kendari dalam menulis surat dinas hanya mencapai 83,14\% dan tidak mencapai criteria ketuntasan klasikal yaitu $85 \%$. Penelitian ini diharapkan memberikan implikasi secara teoritis maupun praktis. Manfaat teoritis penelitian ini adalah hasil penelitiannya bisa memberi pengertian untuk penulis serta pembaca mengenai tehnik menulis surat dinas yang baik dan benar, serta bisa memperluas pendangan serta khasanah pengetahuan terutama dari unsur menulis surat dinas. penelitian ini memiliki manfaat praktis yaitu supaya bisa diterapkan guru dalam menambah kecakapan menulis siswa khususnya dibidang menulis surat dinas.

Melihat banyaknya penelitian terdahulu yang membahasa mengenai kemampuan siswa dalam menulis surat membuktikan bahwa penelitian selanjutnya masih perlu dilakukan guna mengembangkan ilmu menulis kepada siswa. Penelitian ini diharapkan bermanfaat sebagai refernsi dalam pembeharuan pembelajaran menulis surat oleh siswa dan dapat menjadi sumber bagi guru dalam melakukan evaluasi. Dari fenomena yang penulis uraiakan sebelumnya. penulis tertarik melakukan penelitian dengan judul Kemampuan Menulis Surat Tingkat Siswa SMP. Tujuan dari penelitian ini adalah untuk menganalisis Kemampuan Menulis Surat Tingkat Siswa SMP.

\section{Metode}

Metode yang digunakan dalam penelitian ini adalah metode deskriptif. Menurut Arikunto (2014:3) "Penelitian deskriptif adalah penelitian yang dimaksudkan untuk menyelidiki keadaan, kondisi, atau lain-lain yang sudah disebutkan, yang hasilnya dipaparkan dalam bentuk laporan penelitian". Hal ini disebabkan data yang dianalisis dan diinterpretasikan dalam sajian berbentuk deskripsi atau pemaparan. Itu semua dilakukan guna memperoleh gambaran keadaan yang sebenarnya tentang kemampuan siswa kelas VIII SMP 03 Tapung dalam menulis surat dinas. Pada penelitian ini, penulis menggunakan jenis penelitian lapangan, yaitu penulis mendatangi langsung tempat objek penelitian. Tempat yang dimaksud dalam penelitian ini adalah SMP 03 Tapung. Jumlah populasi dalam penelitian ini adalah siswa SMP 03 Tapung sebanyak 60 siswa. Adapun teknik analisis data penelitian ini adalah teknik persentase.

\section{Hasil dan Pembahasan}

Kemampuan siswa dalam menulis surat dinas dapat dicapai dengan cara memberi kesempatan yang cukup kepada siswa untuk mengembangkan bahasa dengan baik. Misalnya, memberikan latihan kepada siswa untuk membuat surat dengan menggunakaan bahasa yang baik dan benar. Selain itu, siswa juga diajarkan dan memperlihatkan struktur yang ada dalam surat dinas. Peran guru sangat dituntut untuk bisa mengajarkan siswa dalam menulis terutama dalam menulis surat dinas. Kurangnya kemampuan siswa dalam menulis surat dinas membuat guru bahasa Indonesia untuk lebih memerhatikan hal tersebut dan lebih membimbing siswanya agar terampil dalam menulis terutama dalam menulis surat dinas dilihat dari segi kemampuan siswa membuat surat berdasarkan struktur surat dinas. Setelah semua itu terwujud maka hasil belajar siswa yang diharapkan adalah siswa terampil dalam menulis surat dinas.

Penelitian ini memfokuskan kajian pada kemampuan menulis surat dinas siswa kelas VIII SMP 03 Tapung. Untuk melihat kemampuan menulis surat dinas siswa kelas VIII SMP 03 Tapung peneliti melakukan tes terhadap siswa dengan menulis contoh surat dinas. Setelah memberikan tugas untuk menulis surat dinas tersebut, peneliti kemudian memeriksa hasil tes berdasarkan aspek-aspek penilaian yang telah ditetapkan. adapun aspek-aspek kemampuan menulis surat dinas yang dimaksud adalah sebagai berikut:

Kesesuaian bentuk surat, dinilai berdasarkan: Semua bagian surat ditulis sesuai dengan pemodelan bentuk surat (nilai 5), Terdapat 1 bagian surat yang tidak ditulis sesuai dengan pemodelan bentuk surat (nilai 4), Terdapat 2-3 bagian surat yang tidak ditulis sesuai dengan pemodelan bentuk surat (nilai 3), Terdapat lebih dari 3 bagian surat yang tidak ditulis sesuai dengan pemodelan bentuk surat (nilai 2), Semua bagian surat tidak ditulis sesuai dengan aturan (nilai 1).

Kelengkapan bagian surat, dinilai berdasarkan: Bagian surat resmi ditulis lengkap (Nilai 5), Terdapat 1-2 bagian surat resmi yang tidak ditulis (Nilai 4), Terdapat 3-4 bagian surat resmi yang tidak ditulis (Nilai 3), 
Terdapat 5-6 bagian surat resmi yang tidak ditulis (Nilai 2), Terdapat lebih dari 6 bagian surat resmi yang tidak ditulis (Nilai 1).

Penulisan bagian surat, dinilai berdasarkan: Semua penulisan bagian surat sudah tepat (Nilai 5), Jumlah kesalahan antara 1 sampai 5 (Nilai 4), Jumlah kesalahan antara 6 sampai 10 (Nilai 3), Jumlah kesalahan lebih dari 10 (Nilai 2), Semua penulisan bagian surat salah (Nilai 1).

Kejelasan Isi Surat, dinilai berdasarkan: Isi surat sesuai dengan topik surat (Nilai 5), Isi surat cukup sesuai dengan topik surat (Nilai 4), Isi surat kurang sesuai dengan topik surat (Nilai 3), Isi surat tidak sesuai dengan topik surat (Nilai 2), Isi surat sangat tidak sesuai dengan topik surat (Nilai 1).

Pilihan Kata, dinilai berdasarkan: Semua pilihan kata sudah tepat/sesuai dengan topik surat (Nilai 5). Terdapat 1-2 kata yang kurang tepat (Nilai 4), Terdapat 3-4 kata yang kurang tepat (Nilai 3), Terdapat 5-6 kata yang kurang tepat (Nilai 2), Hampir semua pilihan kata kurang tepat (Nilai 1).

Tanda Baca dan Ejaan, dinilai berdasarkan: Penggunaan ejaan dan tanda baca sempurna (Nilai 5), Jumlah kesalahan antara 1 sampai 5 (Nilai 4), Jumlah kesalahan antara 6 sampai 15 (Nilai 3), Jumlah kesalahan antara 16 sampai 25 (Nilai 2), Hampir semua penggunaan tanda baca dan ejaan salah (Nilai 1).

Penyusunan Kalimat, dinilai berdasarkan:. Kalimat dalam surat sudah tepat (Nilai 5), Terdapat 1 kalimat yang struktur kalimatnya kurang tepat (Nilai 4), Terdapat 2-3 kalimat yang struktur kalimatnya kurang tepat (Nilai 3), Terdapat lebih dari 3 kalimat yang struktur kalimatnya kurang tepat (Nilai 2), Semua struktur kalimat salah (Nilai 1)

Setelah melakukan penilaian dan menghitung semua skor aspek-aspek kemampuan menulis surat dinas maka akan di rangkum tingkat kemampuan menulis surat berdasarkan berikut (Modifikasi Nurgiantoro, 2016: 277): 86-100 (A) : Sangat Baik, 71-85 (B) : Baik 56-70 (C) : Cukup, $41-55$ (D) : Kurang, $\leq 40$ (E) : Sangat kurang.

Kriteria Penilaian Perskoran Keterampilan Menulis Surat Dinas diatas adalah berdasarkan teori Purwanto (dalamWahyu, 2010: 32-33). Berikut adalah kriteria penilaian ketujuh aspek kemampuan menulis surat dinas diatas: Semua bagian surat ditulis (nilai 5), Terdapat 1 bagian surat yang tidak ditulis (nilai 4), Terdapat 2-3 bagian surat yang tidak ditulis (nilai 3), Terdapat lebih dari 3 bagian surat yang tidak ditulis (nilai 2), Semua bagian surat tidak ditulis (nilai 1).

Tabel 2. Kriteria penilaian aspek kesesuaian bentuk surat

\begin{tabular}{|c|c|c|c|}
\hline Aspek penilaian & Skor & Kriteria Penilaian & Kategori \\
\hline \multirow[t]{5}{*}{$\begin{array}{l}\text { Kesesuaian bentuk } \\
\text { surat }\end{array}$} & 5 & $\begin{array}{l}\text { Semua bagian surat ditulis sesuai dengan } \\
\text { pemodelan bentuk surat }\end{array}$ & Sangat baik \\
\hline & 4 & $\begin{array}{l}\text { Terdapat } 1 \text { bagian surat yang tidak ditulis sesuai } \\
\text { dengan pemodelan bentuk surat }\end{array}$ & Baik \\
\hline & 3 & $\begin{array}{l}\text { Terdapat } 2-3 \text { bagian surat yang tidak ditulis sesuai } \\
\text { dengan pemodelan bentuk surat }\end{array}$ & Cukup \\
\hline & 2 & $\begin{array}{l}\text { Terdapat lebih dari } 3 \text { bagian surat yang tidak ditulis } \\
\text { sesuai dengan pemodelan bentuk surat }\end{array}$ & Kurang \\
\hline & 1 & $\begin{array}{l}\text { Semua bagian surat tidak ditulis sesuai dengan } \\
\text { aturan }\end{array}$ & Sangat kurang \\
\hline
\end{tabular}

Berdasarkan penelitian yang dilakukan ditemukan bahwa rata-rata nilai menulis surat dinas aspek kesesuaian bentuk surat sebesar 65,6 atau dalam kategori kurang. Nilai 15 dengan kategori sangat baik dicapai oleh 3 orang siswa, dengan persentase $5 \%$. Nilai 12 dengan kategori baik dicapai oleh 7 orang siswa, dengan persentase $11,7 \%$. Nilai 9 dengan kategori cukup dicapai oleh 21 orang siswa, dengan persentase $35 \%$. Nilai 6 dengan kategori kurang dicapai oleh 20 orang siswa, dengan persentase 33,3\%. Nilai 3 dengan kategori sangat kurang dicapai oleh 9 orang siswa, dengan persentase 15\%. Dengan merujuk pada hasil tes diatas, maka keterampilan siswa dalam membuat surat dinas sesuai dengan aturan yang berlaku masih tergolong kurang.

Berdasarkan kriteria penilaian diatas, maka dalam penelitian ditemukan rata-rata nilai menulis surat dinas aspek kelengkapan bagian surat sebesar 77,3 atau dalam kategori Baik. Nilai 15 dengan kategori sangat baik dicapai oleh 32 orang siswa, dengan persentase $53,3 \%$. Nilai 12 dengan kategori baik dicapai oleh 4 orang siswa, dengan persentase $16,61 \%$. Nilai 9 dengan kategori cukup dicapai oleh 12 orang siswa, dengan persentase $20 \%$. Nilai 6 dengan kategori kurang dicapai oleh 8 orang siswa, dengan persentase $13,4 \%$. Nilai 3 
dengan kategori sangat kurang dicapai oleh 4 orang siswa, dengan persentase 6,66\%. Dengan merujuk pada hasil tes diatas, maka keterampilan siswa dalam kelengkapan bagian surat tergolong baik.

Tabel 3. Kriteria penilaian aspek kelengkapan bagian surat

\begin{tabular}{llll}
\hline Aspek penilaian & Skor & Kriteria Penilaian & Kategori \\
\hline Kelengkapan Bagian & 5 & Bagian surat dinas ditulis lengkap & Sangat baik \\
Surat & 4 & Terdapat 1-2 bagian surat dinas yang tidak ditulis & Baik \\
& 3 & Terdapat 3-4 bagian surat dinas yang tidak ditulis & Cukup \\
& 2 & Terdapat 5-6 bagian surat dinas yang tidak ditulis & Kurang \\
& 1 & $\begin{array}{l}\text { Terdapat lebih dari 6 bagian surat dinas yang tidak } \\
\text { ditulis }\end{array}$ & Sangat kurang \\
\hline
\end{tabular}

Adapun pedoman peneliti dalam melakukan analisis tes terhadap surat dinas yang ditulis siswa dalam aspek kejelasan isi surat adalah sebagai berikut:

Tabel 5. Kriteria penilaian aspek kejelasan isi surat

\begin{tabular}{llll}
\hline Aspek penilaian & Skor & Kriteria Penilaian & Kategori \\
\hline Kejelasan Isi Surat & 5 & Isi surat sesuai dengan topik surat & Sangat baik \\
& 4 & Isi surat cukup sesuai dengan topik surat & Baik \\
& 3 & Isi surat cukup sesuai dengan topik surat & Cukup \\
& 2 & Isi surat tidak sesuai dengan topik surat & Kurang \\
& 1 & Isi surat sangat tidak sesuai dengan topik surat & Sangat kurang \\
\hline
\end{tabular}

Berdasarkan penilaian kejelasan isi surat, didapatkn rata-rata nilai menulis surat dinas aspek kejelasan isi surat sebesar 64,4 atau dalam kategori cukup. Nilai 15 dengan kategori sangat baik dicapai oleh 32 orang siswa, dengan persentase 53,3\%. Nilai 12 dengan kategori baik dicapai oleh 4 orang siswa, dengan persentase 16,61\%. Nilai 9 dengan kategori cukup dicapai oleh 12 orang siswa, dengan persentase 20\%. Nilai 6 dengan kategori kurang dicapai oleh 8 orang siswa, dengan persentase 13,4\%. Nilai 3 dengan kategori sangat kurang dicapai oleh 4 orang siswa, dengan persentase 6,66\%. Dengan merujuk pada hasil tes diatas, maka keterampilan siswa dalam kejelasan isi surat tergolong cukup. Masih banyak bagian surat resmi tidak ditulis sesuai dengan aturan penulisan surat resmi.

Tabel 6. Kriteria penilaian aspek pilihan kata

\begin{tabular}{llll}
\hline Aspek penilaian & Skor & Kriteria Penilaian & Kategori \\
\hline Pilihan Kata & 5 & Semua pilihan kata sudah tepat/sesuai dengan & Sangat baik \\
& 4 & Topik surat & Baik \\
& 3 & Terdapat 1-2 kata yang kurang tepat & Cukup \\
& 2 & Terdapat 5-6 kata yang kurang tepat & Kurang \\
& 1 & Hampir semua pilihan kata kurang tepat & Sangat kurang \\
\hline
\end{tabular}

Berdasarkan kriteria penilaian, ditemukan rata-rata nilai menulis surat dinas aspek pilihan kata sebesar 63 atau dalam kategori cukup. Nilai 15 dengan kategori sangat baik dicapai oleh 15 orang siswa, dengan persentase 25\%. Nilai 12 dengan kategori baik dicapai oleh 3 orang siswa, dengan persentase 5\%. Nilai 9 dengan kategori cukup dicapai oleh 24 orang siswa, dengan persentase 40\%. Nilai 6 dengan kategori kurang dicapai oleh 12 orang siswa, dengan persentase 20\%. Nilai 3 dengan kategori sangat kurang dicapai oleh 6 orang siswa, dengan persentase $10 \%$. Dengan merujuk pada hasil tes diatas, maka keterampilan siswa dalam aspek pilihan kata tergolong cukup. Masih banyak bagian surat resmi tidak ditulis sesuai dengan aturan penulisan surat resmi.

Adapun pedoman peneliti dalam melakukan analisis tes terhadap surat dinas yang ditulis siswa dalam aspek tanda baca dan ejaan pada tabel 7. Berdasarkan penilaian, ditemukan rata-rata nilai menulis surat dinas aspek pilihan kata sebesar 58,6 atau dalam kategori cukup. Nilai 15 dengan kategori sangat baik dicapai oleh 12 orang siswa, dengan persentase $20 \%$. Nilai 12 dengan kategori baik dicapai oleh 3 orang siswa, dengan persentase 5\%. Nilai 9 dengan kategori cukup dicapai oleh 21 orang siswa, dengan persentase 35\%. Nilai 6 dengan kategori kurang dicapai oleh 17 orang siswa, dengan persentase 28,4\%. Nilai 3 dengan kategori sangat kurang dicapai oleh 7 orang siswa, dengan persentase 11,6\%. Dengan merujuk pada hasil tes diatas, maka 
keterampilan siswa dalam aspek aspek penggunaan tanda baca dan ejaan tergolong cukup. Masih banyak bagian surat resmi tidak ditulis sesuai dengan aturan penulisan surat resmi.

Tabel 7. Kriteria penilaian aspek tanda baca dan ejaan

\begin{tabular}{llll}
\hline Aspek penilaian & Skor & Kriteria Penilaian & Kategori \\
\hline Tanda Baca dan Ejaan & 5 & Penggunaan ejaan dan tanda baca sempurna & Sangat baik \\
& 4 & Jumlah kesalahan antara 1 sampai 5 & Baik \\
& 3 & Jumlah kesalahan antara 6 sampai 15 & Cukup \\
& 2 & $\begin{array}{l}\text { Jumlah kesalahan antara 16 sampai 25 } \\
\text { Hampir semua penggunaan tanda baca dan }\end{array}$ & Kurang \\
& 1 & Sangat kurang salah & \\
\hline
\end{tabular}

Berdasarkan penilaian, ditemukan rata-rata nilai menulis surat dinas aspek pilihan kata sebesar 58,6 atau dalam kategori cukup. Nilai 15 dengan kategori sangat baik dicapai oleh 12 orang siswa, dengan persentase $20 \%$. Nilai 12 dengan kategori baik dicapai oleh 3 orang siswa, dengan persentase $5 \%$. Nilai 9 dengan kategori cukup dicapai oleh 21 orang siswa, dengan persentase 35\%. Nilai 6 dengan kategori kurang dicapai oleh 17 orang siswa, dengan persentase $28,4 \%$. Nilai 3 dengan kategori sangat kurang dicapai oleh 7 orang siswa, dengan persentase $11,6 \%$. Dengan merujuk pada hasil tes diatas, maka keterampilan siswa dalam aspek aspek penggunaan tanda baca dan ejaan tergolong cukup. Masih banyak bagian surat resmi tidak ditulis sesuai dengan aturan penulisan surat resmi.

Adapun pedoman peneliti dalam melakukan analisis tes terhadap surat dinas yang ditulis siswa dalam aspek penyusunan kalimat adalah sebagai berikut:

Tabel 8. Kriteria penilaian aspek penyusunan kalimat

\begin{tabular}{llll}
\hline Aspek penilaian & Skor & Kriteria Penilaian & Kategori \\
\hline Tanda Baca dan Ejaan & 5 & $\begin{array}{l}\text { Semua struktur kalimat dalam surat sudah tepat } \\
\text { Terdapat 1 kalimat yang struktur kalimatnya } \\
\text { kurang tepat }\end{array}$ & Baik \\
& 4 & $\begin{array}{l}\text { Terdapat 2-3 kalimat yang struktur kalimatnya } \\
\text { kurang tepat } \\
\text { Terdapat lebih dari 3 kalimat yang struktur }\end{array}$ & Cukup \\
& 2 & $\begin{array}{l}\text { kalimatnya kurang tepat } \\
\text { Semua struktur kalimat salah }\end{array}$ & Sangat kurang \\
\hline
\end{tabular}

Berdasarkan penilaian, ditemukan rata-rata nilai menulis surat dinas aspek pilihan kata sebesar 58,6 atau dalam kategori cukup. Nilai 15 dengan kategori sangat baik dicapai oleh 8 orang siswa, dengan persentase $13,3 \%$. Nilai 12 dengan kategori baik dicapai oleh 5 orang siswa, dengan persentase $8,3 \%$. Nilai 9 dengan kategori cukup dicapai oleh 34 orang siswa, dengan persentase $56,6 \%$. Nilai 3 dengan kategori sangat kurang dicapai oleh 13 orang siswa, dengan persentase $21,6 \%$. Dengan merujuk pada hasil tes diatas, maka keterampilan siswa dalam aspek aspek penyusunan kalimat tergolong cukup. Masih banyak bagian surat resmi tidak ditulis sesuai dengan aturan penulisan surat resmi.

Penelitian ini berpedoman pada teori Djuhari, Suherli, dan Komaruddin (dalam Dalman 2015:291) yang menyatakan bahwa Bahasa surat merupakan kunci utama dalam menulis surat. Seseorang yang keliru dan kurang teliti dalam menggunakan bahasa di dalam suratnya, maka surat tersebut tidak akan dapat dipahami oleh si pembaca. Bahkan surat tersebut bisa jadi tidak akan dibaca si penerima surat. Oleh karena itu, bahasa yang digunakan dalam menulis surat resmi atau surat dinas haruslah ditulis dengan menggunakan bahasa yang baku, yaitu bahasa yang mengikuti kaidah bahasa yang dibakukan.

Selain itu analisa hasil tes siswa dalam menulis surat dinas jug berpedoman pada teori Nurviati (2008:13) yang menyatakan setiap surat perlu menerapkan prinsip kedayagunaan dan ketepatgunaan". Untuk itu, perlu diperhatikan syarat-syarat dan ciri-ciri surat yang baik adalah: Surat ditulis dalam bentuk yang menarik dan tersusun baik, sesuai dengan peraturan menulis surat, Bahasa yang dipakai hendaknya sesuai dengan maksud surat dan dapat dipahami oleh pembaca. Kata-kata yang dipakai harus tepat, jelas, hemat, dan sesuai dengan ketentuan komposisi, Nada surat hendaknya sopan dan simpatik. Surat harus tulus dan mencerminkan pengertian akan masalah-masalah yang dihadapi penerima surat, Surat tidak mengandung kata-kata atau kalimat-kalimat yang tidak berguna. Penulis hendaknya menulis surta seperti ia sedang berbicara dengan orang yang dituju, Surat tidak terlampau panjang. Surat yang singkat adalah suatu keuntungan. 
Berdasarkan teori diatas, maka analisa hasil tes menulis surat dinas siswa dinilai dari tujuh aspek. Terdapat tujuh (7) aspek dalam penilaian kemampuan menulis surat dinas siswa kelas VIII SMP 03 Tapung. Ketujuh aspek tersebut adalah kesesuaian bentuk surat, kelengkapan bagian surat, penulisan bagian surat, kejelasan isi surat, pilihan kata, tanda baca dan ejaan, serta penyusunan kalimat. Ketujuh aspek ini sudah mencakup kepala surat, nomor surat, alamat surat, lampiran surat, perihal, tanggal surat, alamat surat, bagian salam pembuka, bagian isi surat, dan salam penutup, bagian tanda tangan dan penanggung jawab, tembusan.

Penelitian yang dilkukan dengan teknik analisa hasil tes siswa mendapatkan rata-rata nilai menulis surat dinas aspek kelengkapan bagian surat sebesar 77,3 atau dalam kategori Baik. Rata-rata nilai menulis surat dinas aspek penulisan bagian surat sebesar 77,3 atau dalam kategori baik. Rata-rata nilai menulis surat dinas aspek kejelasan isi surat sebesar 64,4 atau dalam kategori cukup. Rata-rata nilai menulis surat dinas aspek pilihan kata sebesar 63 atau dalam kategori cukup. Rata-rata nilai menulis surat dinas aspek pilihan kata sebesar 58,6 atau dalam kategori cukup

Berdasarkan tes terhadap responden yang dilakukan ditemukan bahwa tingkat kemampuan menulis surat dinas dinas siswa kelas VIII SMP 03 Tapung adalah pada rentang nilai 64,3 atau dengan kategori cukup. dengan demikian hipotesis dalam penelitian ini yaitu Kemampuan menulis surat dinas dinas siswa kelas VIII SMP 03 Tapung berdasarkan sistematika penulisan surat dinas yang telah ditentukan berkategori cukup yaitu 56-74 diterima.

Hasil penelitian sejalan dengan penelitian terdahulu oleh Rini Pramita Sari pada tahun 2010, dengan judul "Kemampuan siswa menulis surat dinas kelas VIII SMP Negeri 01 Benai Kabupaten Kuantan Singingi Tahun Pelajaran 2014/2015. Dalam penelitian Rini Pramita Sari (2010) menemukan dari 20 orang jumlah siswa yang melaksanakan pembelajaran menulis surat dinas, hanya 3 orang yang mendapatkan nilai tertinggi 75-73 dan 17 orang yang mendapatkan nilai rendah 65-40. Dengan persentase ketuntatasan klasikal 15\%, dan skor rata-rata 55. Nilai tersebut belum sesuai dengan kriteria ketuntasan minimal yang ditetapkan di sekolah yakni 70. Persamaan penelitian Rini Pramita Sari dengan penulis lakukan adalah terletak pada metode penelitian dan teknik pengumpulan data penelitian menggunakan teknik tes dan membahas surat dinas. Penelitian terdahulu oleh Rini Pramita Sari, mengukur kemampuan menulis surat dinas siswa kelas VIII SMP Negeri 01 Benai Kabupaten Kuantan Singingi Tahun Pelajaran 2014/2015, dapat dilakukan melalui hasil perhitungan dari penilaian yang telah dilakukan. Rincian tersebut dari kemampuan menerapkan sistematika penulisan surat dinas, Isi surat (alinea pembuka, alinea isi, alinea penutup), Ejaan (pemakaian huruf kapital, penulisan kata depan, pemakaian tanda baca), dan diksi yang dilakukan oleh 2 orang penilai, yaitu guru mata pelajaran bahasa Indonesia di SMP Negeri 01 Benai Ikil (P1) dan peneliti (P2).

\section{Simpulan}

Berdasarkan pengamatan di atas, maka diperoleh kesimpulan : Penelitian menemukan rata-rata nilai menulis surat dinas aspek kelengkapan bagian surat sebesar 77,3 atau dalam kategori Baik. Rata-rata nilai menulis surat dinas aspek penulisan bagian surat sebesar 77,3 atau dalam kategori baik. Rata-rata nilai menulis surat dinas aspek kejelasan isi surat sebesar 64,4 atau dalam kategori cukup. Rata-rata nilai menulis surat dinas aspek pilihan kata sebesar 63 atau dalam kategori cukup. Rata-rata nilai menulis surat dinas aspek pilihan kata sebesar 58,6 atau dalam kategori cukup. Berdasarkan tes terhadap responden yang dilakukan ditemukan bahwa tingkat kemampuan menulis surat dinas siswa kelas VIII SMP 03 Tapung adalah pada rentang nilai 64,3 atau dengan kategori cukup. dengan demikian hipotesis dalam penelitian ini yaitu Kemampuan menulis surat dinas siwa kelas VIII SMP 03 Tapung berdasarkan sistematika penulisan surat dinas yang telah ditentukan berkategori cukup yaitu 56-74 diterima.

\section{Referensi}

Achmad, A. (2011). Bahasa Indonesia Untuk Perguruan Tinggi. Jakarta: Kencana.

Agustin, M. (2019). Kemampuan Menulis Surat Dinas Siswa kelas VII SMP N 11 Kediri. Jurnal BASTRA Vol. 4 No. 2, Edisi April 2019.

Alekdan Achmad. (2011). Bahasa Indonesia Untuk Perguruan Tinggi. Jakarta: Kencana.

Arikunto, S. (2014). Prosedur Penelitian: Suatu Pendekatan Praktik. Jakarta: PT Rineka Cipta.

Dalman. (2014). Keterampilan Menulis. Jakarta: Raja Grafindo Persada.

Dalman. (2018). Keterampilan Menulis. Jakarta: Raja Grafindo.

Darmawati. (2019). Kemampuan Menulis Surat Resmi Dengan Menggunakan Pendekatan Kontekstual Siswa Kelas VII SMP Negeri 8 Palopo. urnal Studi Guru dan Pembelajaran, Vol.2, No. 3, September-December . 
Febri Andira, Adnan, M. Yamin. (2017). Kemampuan Menulis Surat Resmi Siswa Kelas V SD N Garut Aceh Besar . Jurnal Ilmiah Pendidikan Guru Sekolah Dasar.

Hikmah, S. (2019). Kemampuan Menulis Surat Resmi Siswa Kelas VII SMP YLPI P. Marpoyan Pekanbaru . Jurnal Tuah Vol. 1 No. 2, Desember .

Idayanti, R. (2019). Analisis Keterampilan Menulis Surat Dinas Resmi Mahasiswa PGSD Universitas Riau. Jurnal PAJAR (Pendidikan dan Pengajaran) Volume 3 Nomor 5 September 2019.

Jihad, A. A. (2012). Evaluasi Pembelajaran. Yogyakarta: Multi Pressindo.

Kemal, I. (2013). Keterampilan Menulis Surat Dinas. . STKIP BINA BANGSA Volume I Nomor 1. Januari - Juni 2013.

Kurniawan. (2017). Kemampuan Mahasiswa PGSD FKIP Universitas Riau dalam Menulis Surat Resmi. Jurnal Primary Program Studi Pendidikan Guru Sekolah Dasar Fakultas Keguruan dan Ilmu Pendidikan Universitas Riau Volume 6 | Nomor 1.

Kusumaningsih, D dkk. (2013). Terampil Berbahasa Indonesia. Yogyakarta: CV Andi.

Mahsun. (2014). Teks dalam pembelajaran Bahasa Indonesia. Jakarta: Raja Grafindo Persada.

Margono.( 2014). Metodologi Penelitian Pendidikan. Jakarta: PT RinekaCipta.

Moleong, L.J. (2014). Metodologi Penelitian Kualitatif. Bandung: Remaja Rosdakarya.

Nurgiyantoro, B. (2014).Penilaian dalam Pengajaran Bahasa. Yogyakarta: BPFE

Nurgiyantoro, B. (2014). Penilaian dalam pengajaran Bahasa Indonesia. Yogyakarta: BPFE.

Pamungkas, S. (2012). Bahasa Indonesia dalam Berbagai Perspektif. Yogyakarta: ANDI.

Rusman. (2013). Model-Model Pembelajaran : Mengembangkan Profesionalisme Guru. Jakarta: Rajawali Pers.

Saraswati, L. (2015). Mahir Membuat Surat Dinas dalam Sekejap. Yogyakarta: PT Bumi Aksara.

Suparno, Y. (2011). Keterampilan Dasar Menulis. Jakarta: UT.

Suprapto. (2014). Panutan Praktis Surat Menyurat Dinas Resmi Bahasa Indonesia. Bandung: CV Bandar Maju.

Suprapto. (2014). Penuntun Praktis Surat Menyurat Dinas Resmi Bahasa Indonesia. Bandung: CV Bandar Maju.

Sukardi. (2016). Metodologi Penelitian Pendidikan. Jakarta: PT Bumi Aksara.

Suryabrata, S. (2013). Metodologi Penelitian. Jakarta: Raja Grafindo Persada.

Tarigan, H. G. (2013). Menulis Sebagai Suatu Keterampilan Berbahasa. Bandung: Angkasa.

Tabany, T. (2014). Mendesain Model Pembelajaran Inovatif, Progresif, dan Kontekstual. Jakarta: Kencana.

Zabadi, Fairul, Mu' jizah, Murniah, Dad, Sutejo, Parjopo, dan Mujiati, Nok. (2013). Bahasa Indonesia Wahana Pengetahuan Untuk SMP. Jakarta: Kementerian pendidikan dan kebudayaan.

Zainurrahman. (2011). Menulis dari Teori Hingga Praktik. Bandung: Alfabeta 